\title{
Small Bowel Adenocarcinoma in the Setting of Crohn's Disease: A Systematic Review of the Literature
}

\section{Crohn Hastalığıyla İlişkili İnce Bağırsak Adenokarsinomu: Sistematik Derleme}

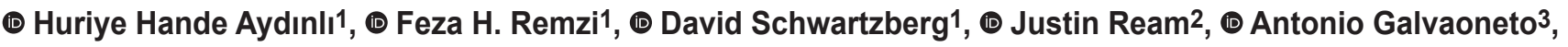 \\ (1) Alec Megibow2 ${ }^{2}$, (1) Leon Pachter ${ }^{1}$
}

${ }^{1}$ New York University Langone Medical Center, Department of Surgery, New York, USA

2New York University Langone Medical Center, Department of Radiology, New York, USA

${ }^{3}$ New York University Langone Medical Center, Department of Pathology, New York, USA

\section{HIIIIIII ABSTRACT}

This study aimed to conduct a systematic literature review of small bowel adenocarcinoma (SBA) associated with small bowel Crohn's disease (CD). A systematic literature review was conducted using MEDLINE, PubMed, Embase, CINAHL, Cochrane and Google Scholar databases. Data regarding demographics, presentation, diagnosis, treatment and survival were extracted. The review included articles that reported the location of SBA in the setting of $\mathrm{CD}$ and excluded articles that did not state the CD location and/or cancer type. We identified 218 patients diagnosed with SBA in the setting of small bowel Crohn's disease. SBA should be in the differential diagnosis in patients with long-standing ileal CD presenting with small bowel obstruction, anaemia and perforation. SBA in the setting of CD presents diagnostic and treatment challenges; however, a high clinical index of suspicion may lead to early diagnosis and increased survival.

Keywords: Adenocarcinoma of the small bowel, Crohn's disease, small bowel cancer

\section{|IIIIIIII| ÖZ}

Bu çalışmanın amacı ince bağırsak Crohn hastalığıyla $(\mathrm{CH})$ ilişkili ince bağırsak adenokanseri (İBA) hakkında sistematik literatür derlemesi yapmaktır. MEDLINE, Pubmed, Embase, CINAHL, Cochrane and Google Scholar portalları kullanılarak sistematik bir derleme yapılmıştır. Hastaların demografik bilgileri, prezentasyon, tanı ve tedavi süreci ve sağkalım bilgileri analiz edilmiştir. Bu derlemeye sadece ince bağırsak $\mathrm{CH}$ kapsayan çalışmalar dahil edilmiş, CH'nin lokalizayonu veya kanser turunun açıkça belirtilmediği çalışmalar derlemeye dahil edilmemiştir. Toplamda ince bağırsak CH ile ilişkili olarak ince bağırsak adenokanseri tanısı alan 218 hasta saptanmıştır. İnce bağırsak adenokarsinomu, uzun sureli ileal CH olan ve ince bağırsak obstruksiyonu, perforasyonu veya anemisi olan hastaların ayırıcı tanısında akılda tutulmalıdır. CH ile ilişkili İBA'sı tanısı ve tedavisi zor bir hastalıktır, ancak yüksek bir şüphe indeksi erken tanı almayı sağlayarak sağkalımı uzatabilir.

Anahtar Kelimeler: İnce bağırsak adenokarsinomu, Crohn hastalığı, ince bağırsak kanseri

\section{Introduction}

Small bowel cancer (SBC) is a rare entity that can be associated with Crohn's disease (CD). ${ }^{1}$ The incidence of SBC in patients with CD is increased 18.75-fold than in the normal population. ${ }^{1}$ The pathogenesis of SBC in the setting of CD is not fully understood, but the disease has a poor prognosis due to diagnostic challenges and concluding late stage presentation associated with the primary disease. This study aimed to conduct a systematic literature review of small bowel adenocarcinoma (SBA) associated with small bowel CD (SBCD).

Address for Correspondence/Yazışma Adresi: Huriye Hande Aydınlı, MD, 


\section{Materials and Methods}

\section{Data Search}

A systematic search on published literature was conducted using the PRISMA guidelines. ${ }^{2}$ The literature search was performed on MEDLINE, PubMed, Embase, CINHAL, Cochrane and Google Scholar, and the databases were searched systematically by screening all publications between January 1947 and January 2017. In addition, Google search engine was used. Citations from the included articles were also searched, but they revealed no other relevant articles. The final query date was 2 January 2017. Information regarding keywords and medical subject headings is summarised in the PRISMA flow (Figure 1). The limitations during search were "species human" and "age $\geq 18$."

\section{Inclusion/Exclusion Criteria}

Case reports, case series, comparative studies, clinical trials, controlled clinical trial, randomised controlled trial and cohort studies were included for PubMed and articles for Embase. Two cases of SBA associated with SBCD from our institution were included as well. Systematic reviews and meta-analyses were excluded. Articles were selected for full text reading if the abstract reported on malignancy in CD. Full text of the relevant studies were retrieved for further selection. Studies containing mixed series of colonic and SBCD were included if data on patients with SBCD diagnosed with SBA could be isolated and extracted. Studies that did not clearly report the location of $\mathrm{CD}$ or studies including only colonic $\mathrm{CD}$, ulcerative colitis, familial adenomatous polyposis and other polyposis syndromes were excluded.

\section{Data Collection and Analyses}

The authors reviewed the full text articles that met the inclusion criteria and extracted information on study population characteristics: age at $\mathrm{CD}$ and SBA diagnosis, gender, initial/presenting symptoms and CD and SBA location, diagnosis timing (preoperative, intraoperative

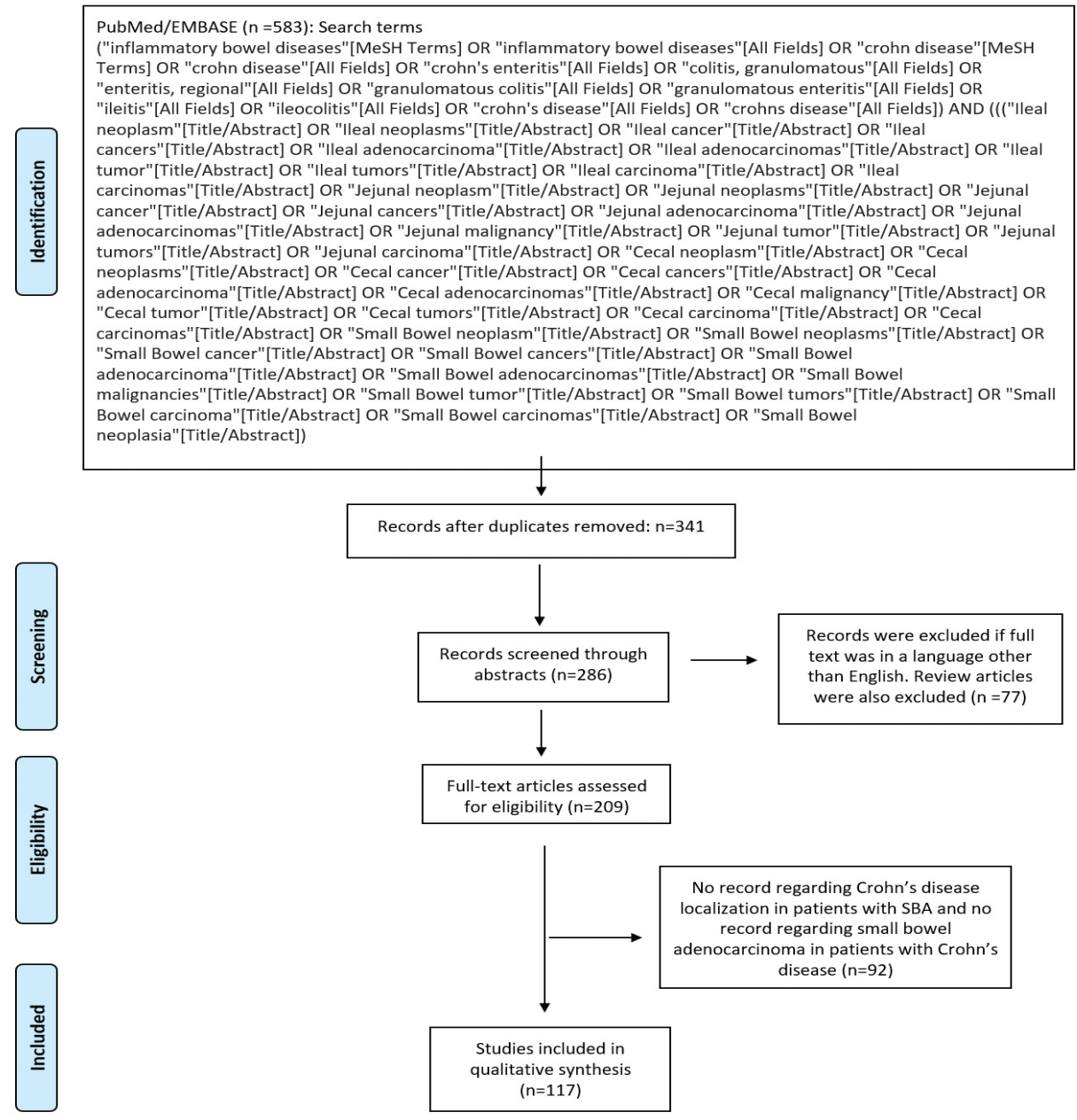

Figure 1. Flow diagram 
and postoperative), tumour location, time from initial diagnosis (CD) to SBA diagnosis, stage/cancer spread $^{3}$ and survival outcomes. The CD location was reported per Vienna classification (Figure 2). ${ }^{4}$ The diagnosis timing of the SBA was grouped into three: preoperatively if the primary tumour and/or the metastasis were diagnosed or suspected for malignancy with preoperative diagnostic studies, intraoperative if the diagnosis of the tumour was made either under direct vision or with frozen pathology report during surgery, and postoperative if the diagnosis was established with postoperative final pathology report. We identified 218 patients from 117 studies ( 2 patients from our institution; unpublished data). .-121 $^{-12}$

\section{Epidemiology}

More than half of the patients with CD experienced SB involvement during their lives. ${ }^{88,122}$ There is a link between $\mathrm{CD}$ and SBA; however, the pathogenesis has not been delineated because of the rarity of the disease. One proposed hypothesis is that chronic inflammation of CD might be the accelerating factor in cancer development, but this theory has not been substantiated. The lifetime prevalence of SBA in patients with SBCD is $0.3-3 \%$, and the risk of SBA is 18.75 times greater in patients with SBCD than in the general population. ${ }^{1,21,55,77,119}$ A single-centre study identified only one SBA in 295 CD patients (0.3\%) during a 30-year period. ${ }^{21} \mathrm{CD}$ associated with SBA is reported to be more frequent among men with a male-to-female ratio of 3:1; however, there is no gender-related difference in the prevalence of non-CD associated with SBA. ${ }^{48,123}$

We identified 218 patients from the literature, including two unpublished cases from our institution, who were diagnosed

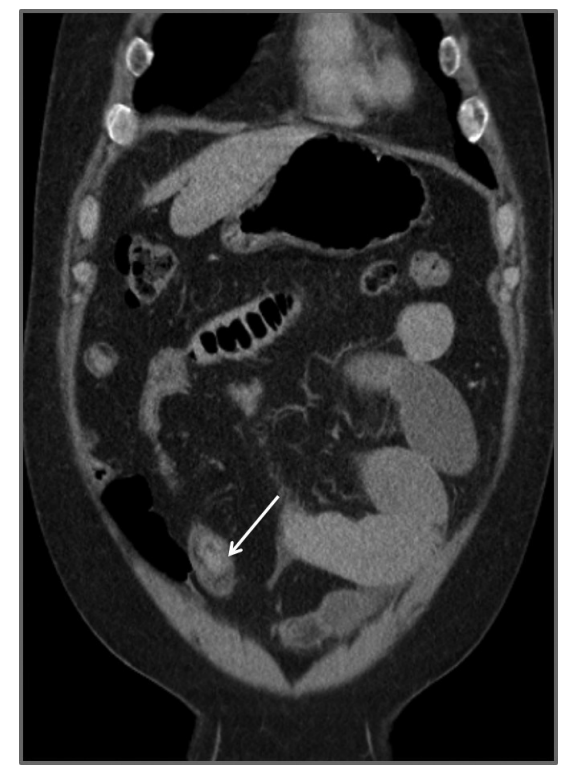

Figure 2. Computed tomography enterography from 2015 reveals changes of Crohn's disease affecting the mid to distal ileum (arrow) with SBA in the setting of SBCD. The detailed information regarding our cohort is summarised in Table 1.

In a comparative study, patients diagnosed with SBA in the setting of SBCD were younger than those diagnosed with sporadic SBA [43 (33-72) vs 48 (41-95) years old]. ${ }^{80}$ Although there are no recommendations for screening SBA in patients with $C D$, keeping the diagnosis germane to the clinician might impact diagnosis timing. In our cohort, the mean age of SBA diagnosis was 50.6 (range 24-86) years. The male predominance was consistent with the literature.

\section{Risk Factors}

Multiple risk factors have been proposed to play a role in the development of SBA in patients with CD. ${ }^{124}$ Adenocarcinoma development in the setting of previous strictureplasty site has been reported in four cases, ${ }^{75,78,82,109}$ and adenocarcinoma development in the stricture site has been reported in eight cases. ${ }^{46,68,69,70,73,81,87,89}$ Partridge and Hodin ${ }^{78}$ described malignant transformation in patients with a history of strictureplasty as being a (1) development of a new cancer in the area of previous strictureplasty and (2) failure to recognise the cancer due to the limited intervention without $\mathrm{SB}$ resection. The absence of a well-defined mass in most of the cases might preclude the diagnosis (Figure 3); thus, biopsy of the strictures adjacent to mucosal ulcers might be useful if there is a clinical concern, especially in longstanding disease. ${ }^{78} \mathrm{~A}$ case report revealed a 49-year-old man with long-standing $C D$ who underwent surgery due to SB obstruction and was subsequently diagnosed with multiple SB strictures in an ulcer adjacent to a stricture on intraoperative biopsy. An inconclusive frozen pathology report led to the decision to perform SB resection (Figure 4). SBA was identified in the final pathological specimen. ${ }^{78}$ Marchetti et al. ${ }^{68}$ reported another case where a biopsy of a stricture secondary to ileal CD was performed before Heineke-Mikulicz strictureplasties. Biopsies were negative

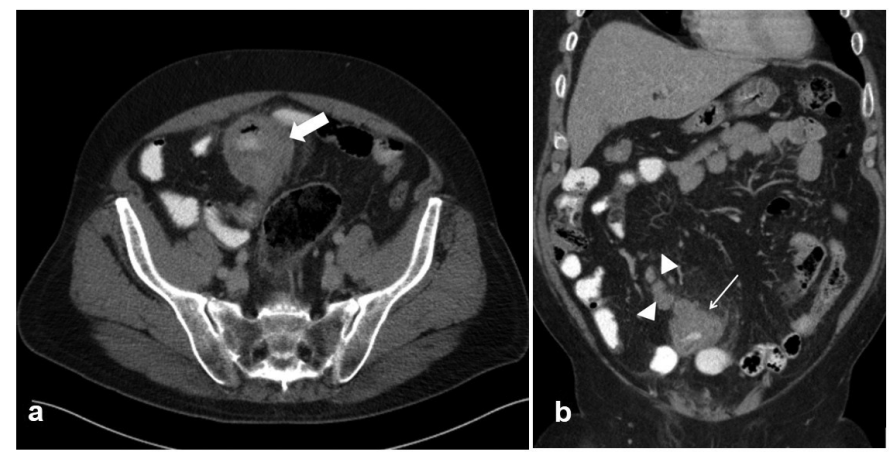

Figure 3. a) Axial computed tomography (CT) image obtained 15 months later shows bulky mass with soft tissue attenuating wall (arrow) representing the adenocarcinoma. b) CT from the same patient/time reveals that a soft tissue mass has grown within the previously affected bowel loop (arrow) with associated infiltrative changes in the local small bowel mesentery. Multiple lymph nodes have also appeared (arrowheads) 
at the time of surgery, but 6 years after the surgery, the patient was diagnosed with adenocarcinoma at the site of prior strictureplasty, which was identified by a previously placed clip. In spite of these two case reports, the overall risk of SBA in the strictureplasty site is so low that routine biopsy of all strictures is not warranted. ${ }^{68}$

The presence of an intra-abdominal fistula is another pathologic state that has been proposed to be associated with SBA development in patients with $\mathrm{CD}{ }^{71,96}$ However, it is unclear whether the SBA originates at the fistula site or fistulas occur secondary to SBA. Irrespective of the above theories, the incidence of SBA in the setting of intra-abdominal fistula associated with $\mathrm{CD}$ is extremely rare. A previous history of bypassed bowel segments is also a risk factor and has been reported in numerous cases. ${ }^{5,10,11,12,13,14,15,16,17,18,19,20,22,24,38,40,41,49,65}$ Bacterial inoculation

Table 1. Information regarding 216 patients-cohort collected with literature review

Age at the diagnosis of $C D$, years ${ }^{*}, \quad 34.4$ (6-78) age $<40$ years old: 134 patients, age $\geq 40$ years old: 77 patients

Gender $^{1}$

78 female, 127 male

Age at the diagnosis of SBA*,1

50.6 years (range $24-86$ )

20.7 (range 1-300)

Disease duration, months ${ }^{1}$

27 patients diagnosed with cancer during their initial visit and they didn't included in the calculation of disease duration

L1: 117

Location of the CD, $\mathrm{n} \quad$ L1-L4: 18

L1: Terminal ileum L2-L4: 2

L2: Colon L3: 36

L3: Ileocolic L3-4: 6

L4: Upper gastrointestinal tract L4: 13

Diffuse small bowel CD or enteritis: 24

Bypassed bowel segment

24 patient have history of bypass and 22 of these patients had the SBA in the bypassed segments

Intraabdominal fistula

4 patients had the SBA in the fistula site

Stricture/stricturoplasty

12 patients have history of SB stricture, 8 patients developed cancer in the stricture site, 4 developed cancer in the stricturoplasty site

-206 patients with one adenocarcinoma:

Ileum- 154, Jejunum- 28, SB- 18 (no details)

Jejunoileal- 4, Ileocolic- 2

Location of the cancer

-10 patients with more than one adenocarcinoma:

Ileum-colon- 7, Duodenum- ileum- 1, Jejunum-ileum- 1, Jejunum-ileum-colon-1

In addition to adenocarcinoma 4 patients were diagnosed with colorectal carcinoid tumors at the diagnosis.

Presenting symptoms

82 obstruction, 12 pain, 11 anemia/bleeding, 10 diarrhea, 8 perforation/peritonitis, 5 fistula, 3 flare, 2 ileus, 2 mass, 2 fatigue, 1 high stoma output.

In 132 patients followed with a mean follow up time of 19 mo (0.1-156 mo), 4 patients were reported

Survival ${ }^{\S, 1}$ to die within a year of surgery- no details. 68/128 patients (53.1\%) were alive at 1 year, 36/118 patients (30.5\%) were alive at 2 year.

A total of 37 patients had information;

$27 / 75$ patients (36\%) in stage $4,4 / 33$ patients (12.1\%) in stage 3 ,

Chemotherapy (CT)

$4 / 46$ patients $(8.7 \%)$ with stage 2 and $1 / 16$ patients $(6.3 \%)$ with stage 1 . One patient was missing data on tumor stage.

21 patients received 5-FU based adjuvant CT, 1 patient received oxaliplatin, 15 patients received adjuvant CT- no specific info

Stage 1 - 16 patients (9.4\%), Stage 2- 46 patients (27.1\%), Stage 3- 33 patients (19.4\%), and Stage $4-75$ patients (44.1\%)

Disease stage, $\mathrm{n}^{1}$

(25 to carcinomatosis/mesentery/peritoneal, 19 to liver, 5 to lung, 2 to brain, 2 to ovary, 2 to colon, 27 not reported)

${ }^{1}$ Missing data : Age: 6 patients, gender:11, age at the SBA diagnosis: 11 patients, disease duration: 7 patients, survival: 72 patients, disease stage: 46 patients

*Reported values mean (range), ${ }^{8}$ Only patients who underwent surgery included, CT: Chemotherapy 


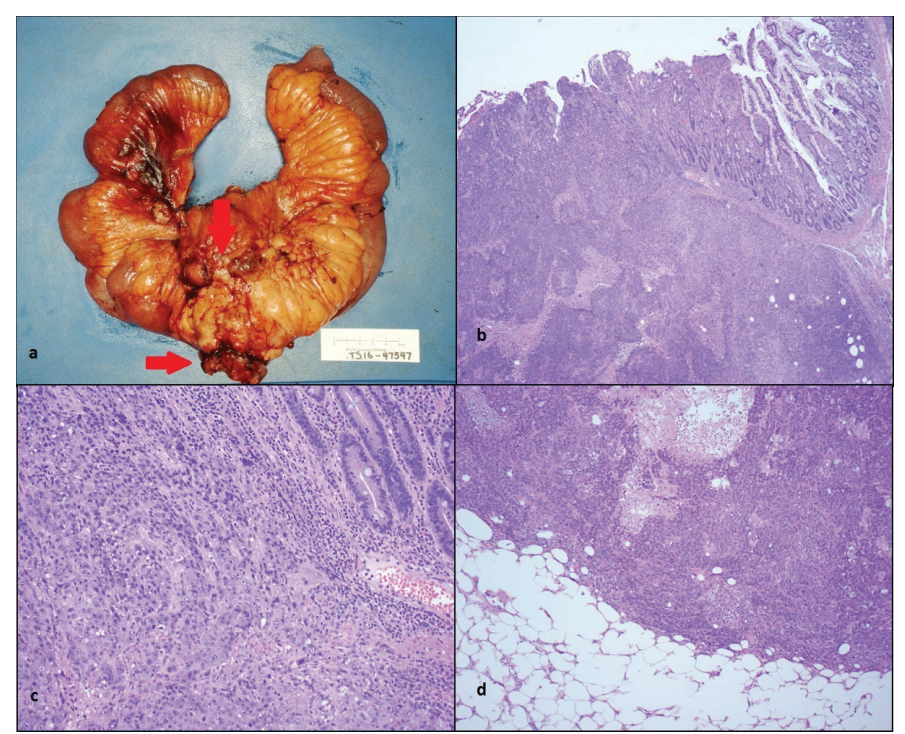

Figure 4. a) Gross image of the small bowel resection (red arrows are pointing to the tumour). b) High power view of the tumour (left) and benign small intestine (right). c) Low power view of the tumour (left) and benign small intestine (right). d) Tumour invasion of the peri-intestinal fat tissue

might also affect pathophysiology. ${ }^{125}$ In a matched casecontrol study, occupational exposure to halogenated aromatic compounds and aliphatic amines, asbestos, cutting oil solvents and abrasives were shown to have a relationship with SBA development in CD. ${ }^{51}$

Additionally, some have suggested that medications used to control CD such as 6-mercaptopurine might contribute to cancer development when the drug is used for more than 6 months. ${ }^{51,52}$ However, further observational studies are needed.

\section{Presentation}

These patients present with various symptoms that vary from non-specific fatigue to bleeding and complete obstruction. ${ }^{69,76,83}$ Usually, the symptoms are subtle and indistinguishable from $\mathrm{CD}$ and, therefore, might be a risk factor contributing to a diagnostic delay of SBA. In some cases, the predominant initial presentation may be that of SBA rather than CD. ${ }^{72,91,121}$ The initial findings of SBA in the setting of $\mathrm{CD}$ are intestinal obstruction, followed by abdominal pain, diarrhoea, weight loss and abdominal fistulae. ${ }^{42,65,108}$ In this review, obstruction was the most common initial symptom ( $\mathrm{n}=82,59 \%$; missing data in 77 patients). Other common symptoms were abdominal pain $(n=12)$, anaemia-bleeding $(n=11)$, diarrhoea $(n=10)$ and fistulas $(n=5)$. Additionally, the incidental finding of SBA during screening colonoscopy with retrograde ileoscopy may be the first presentation of the disease. Incidental identification of liver metastasis with biopsy has also been reported in the literature. ${ }^{86,96}$ Free perforations in the setting of $\mathrm{CD}$ should arouse suspicion as to the possibility of SBA..$^{87,94}$

SBA associated with CD is usually related to the ileum. ${ }^{23,65,77,80}$ Palascak-Juif et al. ${ }^{80}$ reported on 19 of 20 patients who were diagnosed with ileal SBA in the setting of CD. On the other hand, de novo SBA is equal throughout the proximal and distal SB. ${ }^{126}$ In this review, there were 206 patients with one adenocarcinoma and 10 patients with two different adenocarcinomas. Among the patients with only one tumour, 154 patients $(74.7 \%)$ had ileal SBA. The time from the initial CD diagnosis to the development of SBA is longer compared with other benign indications for surgery. ${ }^{23}$ In the literature, the time lapse between diagnoses of $C D$ and SBA ranged from 3 weeks to 15 years; in the current review, 25 patients (11.6\%) were diagnosed with cancer within a month of their CD diagnosis. The median time to SBA diagnosis from CD diagnosis was 18 months (1-300 months, data on 10 patients were missing). However, it is important to acknowledge that the delay in the initial diagnosis of $C D$ might be a factor contributing to the delay in diagnosing SBA.

\section{Pathophysiology and Pathology}

To date, the pathophysiology of SBA has not been delineated. ${ }^{89}$ An inflammation-dysplasia-adenocarcinoma process has been suggested to affect the development of SBA in CD similar to the colorectal cancer (CRC) ${ }^{71,89}$ In a retrospective study, similar phenotypic features of the dysplastic areas in SBA and CRC have been illustrated. ${ }^{89}$ Recognised CRC genetic mutations such as K-Ras, APC and mismatch repair genes have been shown to be present in CRC and de novo SBA. ${ }^{127,128,129}$ The presence of p53, K-Ras mutations or high microsatellite instability in the setting of CD-related SBA has also been documented in the literature. ${ }^{71,115}$

The incidence of sporadic SBA and carcinoid tumours has been reported to be equal in the most recent national reports. ${ }^{126}$ However, adenocarcinoma is more common in the setting of CD than carcinoid tumour. ${ }^{114} \mathrm{SBA}$ is commonly diagnosed as an isolated tumour, occasionally synchronous with colonic adenocarcinomas or SB carcinoid tumours. . $7,59,107,111,114$ Four cases of concurrent SBA and carcinoid tumour in the setting of $C D$ have been identified in the literature..$^{59,107,111,114}$

\section{Diagnosis}

Commonly, the diagnosis of SBA in the setting of $\mathrm{CD}$ is incidental and made postoperatively. The challenge, however, is to make the diagnosis preoperatively and ensure timely extirpation..$^{83,91}$ The delays in the diagnosis were less than 2 months due to the failure of patients to report their symptoms, 8.2 months due to the absence of appropriate 
diagnostic tests and 12 months due to the failure of detection on the radiological tests in patients with primary SBC. ${ }^{130}$ Patients more commonly undergo exploratory laparotomy to treat the complications of Crohn's flair including obstruction, infection, bleeding and perforation rather than the rare diagnosis of SBA. Out of 129 patients, $64(49.6 \%)$ were diagnosed with cancer after the surgical procedure, whereas $46(35.6 \%)$ and 15 (11.6\%) were diagnosed intraoperatively and preoperatively, respectively. Four patients (3.2\%) were diagnosed at autopsy without any surgical interventions, and data were missing in 87 patients. Currently, preoperative diagnostic tools are insufficient to differentiate SBA from complicated CD. To identify malignancy preoperatively, clinicians should consider it to be the differential diagnosis, particularly in patients with new symptom onset or recurrent SB obstruction after a longstanding stable disease, fistula tracks resistant to treatment and recurrent stricture after a recent stricturoplasty (Figure 5). ${ }^{45}$

\section{Imaging and Endoscopy}

Imaging studies are not fully reliable to diagnose SBA in the setting of SBCD as chronic inflammation of CD maybe indistinguishable from a tumour-desmoplastic reaction..$^{85,131}$ Standard imaging techniques such as computed tomography (CT) ${ }^{25}$ barium enema, ${ }^{12,40}$ upper gastrointestinal and SB series, ${ }^{44,47,50}$ magnetic resonance enterography, ${ }^{86}$ positron emission tomography/CT and double-balloon enteroscopy ${ }^{14}$ may be helpful in enabling the diagnosis, but these sophisticated studies may only identify a small portion of malignancies in these cases preoperatively. ${ }^{47,84}$

Small bowel enteroclysis and SB that follow through exams detected $90 \%$ and $33 \%$ of SB tumours in non-CD patients, respectively, but neither one is commonly utilised. ${ }^{132}$
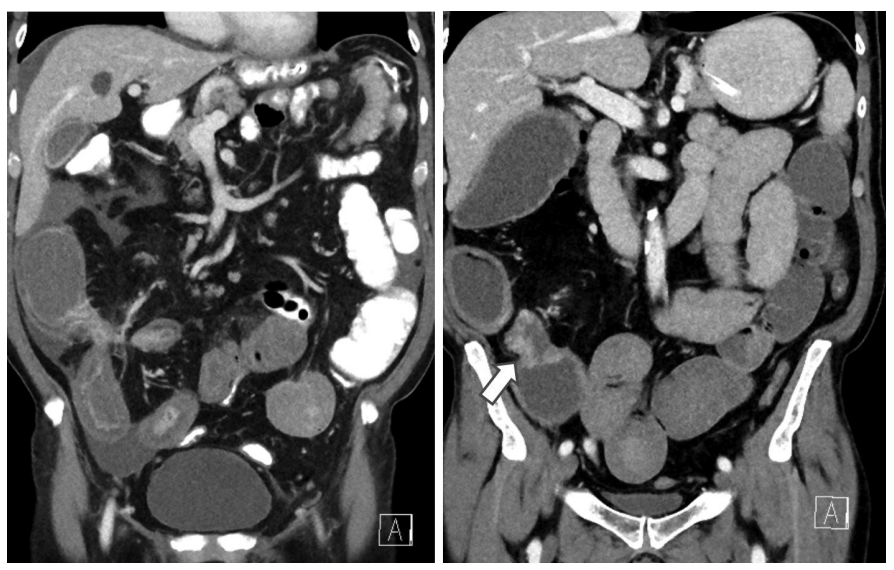

Figure 5. Patient with long-standing penetrating/fistulising CD with nonresponsive bowel obstruction necessitating surgical resection. At surgery, an adenocarcinoma was found embedded in the CD changes. Although this was not prospectively recognised, in review, there are some irregular nodular mural changes in the affected region (arrow)
Conversely, CT enterography has become the imaging modality of choice, and it has been widely adopted for both the initial diagnosis and follow-up of SBA in patients with CD. ${ }^{79}$ Although video capsule endoscopy has been used as an important endoscopic tool, the presence of $\mathrm{CD}$ increases the risk of capsule retention as a result of $\mathrm{CD}$ stricture formation. ${ }^{133}$

The radiological diagnosis of SBA in patients with $C D$ has been historically challenging. Weber et al. ${ }^{131}$ reviewed $34 \mathrm{CD}$ patients with SBA, of whom 14 had preoperative imaging. They also enumerated 17 imaging features that might suggest the presence of tumours, including mass, obstruction, annular mass morphology, active inflammation with abscess cavity, perforation, abrupt luminal margins, nodularity at the mesenteric border of the mass, homogeneous enhancement patterns, bowel wall thickening, presence of penetrating disease near mass lesion or elsewhere, aneurysmal bowel dilatation and localised mesenteric stranding or metastatic disease to liver or elsewhere. Patients with malignancy at an ileocolic anastomosis were excluded. Despite the abovementioned features, only 2 of the 14 cases were prospectively diagnosed. ${ }^{131}$ In a separate study, Soyer et al. ${ }^{85}$ reported that only five of seven SBA in CD patients could be retrospectively identified on CT enterography. They listed SB mass, heterogeneous strictures, high-grade obstruction or irregular and circumferential bowel wall thickening as suggestive features of identifying SBA. ${ }^{85}$ Both reports highlighted the overlap of imaging findings in patients with long-standing $C D$ with or without superimposed adenocarcinoma. The ability to use diffusion restriction as an imaging parameter allowed for the prospective diagnosis of two SBAs in CD. ${ }^{86}$ However, both cases were described as bulky masses that would have likely been diagnosed by other modalities such as CT or barium studies.

\section{Treatment and Prognosis}

Therapy options are limited, and surgery is the main stay of management when feasible. Locoregional SBA is treated with wide resection and lymph node dissection. Lymph node spread is commonly seen in patients with jejunal or ileal adenocarcinomas, which are the locations frequently observed in SBA in the setting of $\mathrm{CD}^{47,134}$ For tumours confined in the terminal ileum, adequate SB margins plus a formal right colectomy are indicated to properly remove the tumour and lymph node basin. Adjuvant chemotherapy with different regimens has been recommended and used in patients with positive lymph nodes, but a recent retrospective study reported no statistically significant difference in disease-free survival and overall survival with or without neoadjuvant therapy. ${ }^{124}$ The rationale behind using adjuvant chemotherapy to treat SBA is mainly to prevent recurrent 
disease, akin to the management principles of the colonic adenocarcinoma. Small numbers preclude prospective clinical trials on specific regimens. ${ }^{135}$ The literature largely consists of case reports and case series. We identified 75 patients (44.1\%) with distal metastasis and 33 (19.4\%) with lymph node metastasis at the time of diagnosis. The locations of distal organ metastasis and incidences are summarised in Table 1. The regimens used for adjuvant therapy showed great heterogeneity with regimens including fluorouracil (5-FU), 5-FU and leucovorin, 5-FU with lomustine, cyclophosphamide with methotrexate (in a patient where 5-FU was not available), folinic acid, 5-FU and oxaliplatin (FOLFOX), FOLFOX and cetuximab, 5-FU and steroids, and oxaliplatin, bevacizumab and capecitabine. Of 75 patients with metastasis, only 27 had information regarding adjuvant therapy. Among 62 patients (32.6\%) with local disease and negative lymph nodes, 5 received adjuvant chemotherapy. Combination 5-FU and leucovorin in patients with SBA and combination capecitabine and oxaliplatin have been shown to improve the outcome in metastatic disease in a phase II trial. ${ }^{136,137,138}$

After the failure of 5-FU, irinotecan might be beneficial in patients with SBA in the setting of CD. ${ }^{139}$ The prognosis of $\mathrm{SBA}$ in the setting of $\mathrm{CD}$ has been a subject of controversy in the literature. Many reports suggested worse outcomes in patients with SBA in the setting of CD compared with those in de novo SBA. ${ }^{43,44,48,65}$ In young patients with distally located SBA in the presence of CD-like symptoms including abdominal pain, fatigue and weight loss, the diagnosis has been delayed, thus affecting the prognosis. When patients present with obstruction and are diagnosed with SBA, the disease is typically advanced and cannot achieve a cure with surgical treatment alone. ${ }^{83}$ The 2-year survival rate in patients with SBA in the setting of CD was $27 \%$, whereas the 5 -year survival rate was $32.5 \%$ in patients with de novo SBA unrelated to CD in the SEER database. ${ }^{83,126}$ In this review, $36.7 \%$ (18/49 patients) of patients operated for obstruction were alive at 1 year and $15.2 \%$ ( $7 / 46$ patients) at 2 years. Although these percentages are lower than other studies reported in the literature, data were missing in 34 patients, which might have affected the outcomes. Palascak-Juif et al. ${ }^{80}$ reported a median survival rate of 28 (range 7-26) months compared with that of 12 (2-74) months survival in patients with de novo SBA, yet half of their patients with $\mathrm{CD}$ received adjuvant chemotherapy, whereas none in the de novo group did. Weber et al. ${ }^{131}$ reported their experience with SBA in CD and showed that $70 \%$ of patients were alive at 1 year and $52 \%$ at 2 years. However, only $73.5 \%$ of their patients were available for follow-up. In our cohort, 1-year and 2-year survival rates were $53.1 \%(68 / 128)$ and $30.5 \%$ (36/118), respectively, which are comparable to the data reported in the literature. Of patients, $66 \%$ were followed up with subsequent survival information. The difference in the outcomes is multifactorial, and prospective studies with matched cohorts are needed to generate evidence-based data upon to provide recommendations.

\section{Summary}

We report a meta-analysis of SBA in the setting of CD and have summarised the challenges of timely diagnosis, surgical and adjuvant treatment and survival outcomes in complicated SBA in the presence of CD. With a delay in diagnosis already present, further concern that an increase in the availability of biologics may only delay referral for timely surgery and prompt diagnosis of this highly aggressive cancer.

Peer-review: Internally peer reviewed.

\section{Authorship Contributions}

Surgical and Medical Practices: H.H.A., F.H.R., D.S., J.R., A.G., L.P., Concept: H.H.A., F.H.R., D.S., J.R., A.G., L.P., Design: H.H.A., F.H.R., D.S., J.R., A.G., L.P., Data Collection or Processing: H.H.A., F.H.D., L.P., Analysis or Interpretation: H.H.A., F.H.R., D.S., J.R., A.G., L.P., Literature Search: H.H.A., F.H.D., L.P., Writing: H.H.A., F.H.R., D.S., J.R., A.G., L.P.

Conflict of Interest: No conflict of interest was declared by the authors.

Financial Disclosure: The authors declared that this study received no financial support.

\section{References}

1. Laukoetter MG, Mennigen R, Hannig CM, Osada N, Rijcken E, Vowinkel T, Krieglstein CF, Senninger N, Anthoni C, Bruewer M. Intestinal cancer risk in Crohn's disease: a meta-analysis. J Gastrointest Surg 2011;15:576-583.

2. Liberati A, Altman DG, Tetzlaff J, Mulrow C, Gøtzsche PC, Ioannidis JPA, Clarke M, Devereaux PJ, Kleijnen J, Moher D. The PRISMA statement for reporting systematic reviews and meta-analyses of studies that evaluate health care interventions: explanation and elaboration. J Clin Epidemiol 2009;339:b2700.

3. Coit DG KD, Tang LH, et al. Small Intestine. In: MB A, ed. AJCC Cancere Staging Manual. AJCC 2017:221.

4. Gasche C, Scholmerich J, Brynskov J, D'Haens g, Hanauer SB, Irvine EJ, Jewell DP, Rachmilewitz D, Sachar DB, Sandborn WJ, Sutherland LR. A simple classification of Crohn's disease: report of the Working Party for the World Congresses of Gastroenterology, Vienna 1998. Inflamm Bowel Dis 2000;6:8-15.

5. Weingarten B, Parker JG, Chazen EM, Jacobson HG. Adenocarcinoma of the jejunum in nonspecific granulomatous enteritis. AMA Arch Surg 1959;78:483-489

6. Ginzburg L, Schneider KM, Dreizin DH, Levinson C. Carcinoma of the jejunum occurring in a case of regional enteritis. Surgery 1956;39:347351 .

7. Kornfeld P, Ginzburg L, Adlersberg D. Adenocarcinoma occurring in regional jejunitis. Am J Med 1957;23:493-498.

8. Bersack SR, Howe JS, Rehak EM. A unique case with roentgenologic evidence of regional enteritis of long duration and histologic evidence of diffuse adenocarcinoma. Gastroenterology 1958;34:703-710. 
9. Buchanan DP, Huebner GD, Woolvin SC, North RL, Novack TD Carcinoma of the ileum occurring in an area of regional enteritis. Am J Surg 1959;97:336-339.

10. Zisk J, Shore JM, Rosoff L, Friedman NB. Regional ileitis complicated by adenocarcinoma of the ileum: a report of two cases. Surgery 1960;47:970974.

11. Steele DC, Mc ND. Adenocarcinoma arising in a site of chronic regional enteritis. Can Med Assoc J 1960;83:379-381.

12. Weingarten B, Weiss J. Malignant degeneration in chronic inflammatory disease of the colon and small intestine. Am J Gastroenterol 1960;33:203207.

13. Hoffert PW, Weingarten B, Friedman LD, Morecki R. Adenocarcinoma of the terminal ileum in a segment of bowel with coexisting active ileitis. N Y State J Med 1963;63:1567-1571.

14. Wyatt AP. Regional enteritis leading to carcinoma of the small bowel. Gut 1969; 10:924-927

15. Tyers GF, Steiger E, Dudrick SJ. Adenocarcinoma of the small intestine and other malignant tumors complicating regional enteritis: case report and review of the literature. Ann Surg 1969;169:510-518.

16. Schuman BM. Adenocarcinoma arising in an excluded loop of ileum. N Engl J Med 1970;283:136-137.

17. Goldman LI, Bralow SP, Cox W, Peale AR. Adenocarcinoma of the small bowel complicating Crohn's disease. Cancer 1970;26:1119-1125.

18. Brown N, Weinstein VA, Janowitz HD. Carcinoma of the ileum 25 years after bypass for regional enteritis. A case report. Mt Sinai J Med 1970;37:675-677.

19. Farmer RG, Hawk WA, Turnbull RB Jr. Carcinoma associated with regional enteritis. Report of 2 cases. Am J Dig Dis 1970;15:365-371.

20. Bruni H, Lilly J, Newman W, 3rd, McHardy G. Small bowel carcinoma as a complication of regional enteritis. South Med J 1971;64:577-580.

21. Fielding JF, Prior P, Waterhouse JA, Cooke WT. Malignancy in Crohn's disease. Scand J Gastroenterol 1972;7:3-7.

22. Schofield PF. Intestinal malignancy and Crohn's disease. Proc R Soc Med 1972;65:783-784

23. Darke SG, Parks AG, Grogono JL, Pollock DJ. Adenocarcinoma and Crohn's disease. A report of 2 cases and analysis of the literature. Br J Surg 1973;60:169-175

24. Frank JD, Shorey BA. Adenocarcinoma of the small bowel as a complication of Crohn's disease. Gut 1973;14:120-124.

25. Fleming KA, Pollock AC. A case of 'Crohn's carcinoma'. Gut 1975;16:533537

26. Berman LG, Prior JT. Adenocarcinoma of the small intestine occurring in a case of regional enteritis. J Mt Sinai Hosp N Y 1964;31:30-37.

27. Sheil FO, Clark CG, Goligher JC. Adenocarcinoma associated with Crohn's disease. Br J Surg 1968;55:53-58.

28. Almond $\mathrm{CH}$, Neal MP, Moedl KR. Regional ileitis with coincident ileal carcinoma. Mo Med 1960;57:452-454.

29. Cantwell JD, Kettering RF, Carney JA, Ludwig J. Adenocarcinoma complicating regional enteritis: report of a case and review of the literature. Gastroenterology 1968;54:599-604.

30. Morowitz DA, Block GE, Kirsner JB. Adenocarcinoma of the ileum complicating chronic regional enteritis. Gastroenterology 1968;55:397402

31. Magnes M, DeBell P. Carcinoma associated with terminal ileitis. J Med Soc N J 1969;66:573-574.

32. Rha CK, Wilson JM, Jr., Klein NC. Adenocarcinoma of the ileum with coexisting regional enteritis. Arch Surg 1971;102:630-633.

33. Papp JP, Pollard HM. Adenocarcinoma occurring in Crohn's disease of the small intestine. Am J Gastroenterol 1971;56:149-156.
34. Beachley MC, Lebel A, Lankau CA, Jr., Rothman D, Baldi A. Carcinoma of the small intestine in chronic regional enteritis. Am J Dig Dis 1973; 18:10951098.

35. Crystal RF. Letter: Development of carcinoma in regional enteritis. Arch Surg 1974;109:124

36. Saeed W, Kim S, Burch BH. Development of carcinoma in regional enteritis. Arch Surg 1974;108:376-379.

37. Lightdale CJ, Sternberg SS, Posner G, Sherlock P. Carcinoma complicating Crohn's disease. Report of seven cases and review of the literature. Am J Med 1975;59:262-268.

38. Greenstein AJ, Janowitz HD. Cancer in Crohn's disease. The danger of a by-passed loop. Am J Gastroenterol 1975;64:122-124.

39. Newman RD, Bennett SJ, Pascal RR. Adenocarcinoma of the small intestine arising in Crohn's disease. Demonstration of a tumor-associated antigen in invasive and intraepithelial components. Cancer 1975;36:2016-2019.

40. Nesbit RR Jr, Elbadawi NA, Morton JH, Cooper RA Jr. Carcinoma of the small bowel. A complication of regional enteritis. Cancer 1976;37:29482959.

41. Hoffman JP, Taft DA, Wheelis RF, Walker JH. Adenocarcinoma in regional enteritis of the small intestine. Arch Surg 1977;112:606-611.

42. Greenstein AJ, Sachar D, Pucillo A, Kreel I, Geller S, Janowitz HD, Aufses A Jr. Cancer in Crohn's disease after diversionary surgery. A report of seven carcinomas occurring in excluded bowel. Am J Surg 1978;135:86-90.

43. Floch HF, Slattery LR, Hazzi CG. Carcinoma of the small intestine in regional enteritis: presentation of a case and review of the literature. Am J Gastroenterol 1978;70:520-527

44. Fresko D, Lazarus SS, Dotan J, Reingold M. Early presentation of carcinoma of the small bowel in Crohn's disease ("Crohn's carcinoma"). Case reports and review of the literature. Gastroenterology 1982;82:783-789.

45. Kerber GW, Frank PH. Carcinoma of the small intestine and colon as a complication of Crohn disease: radiologic manifestations. Radiology 1984;150:639-645.

46. Leader M, Jass JR. Increased alpha-fetoprotein concentration in association with ileal adenocarcinoma complicating Crohn's disease. J Clin Pathol 1984:37:293-297.

47. Ouriel K, Adams JT. Adenocarcinoma of the small intestine. Am J Surg 1984;147:66-71.

48. Collier PE, Turowski P, Diamond DL. Small intestinal adenocarcinoma complicating regional enteritis. Cancer 1985;55:516-521.

49. Watanabe M, Nakano H, Takano E, Miyachi I, Ito M, Kawase K. A case of small bowel carcinoma in Crohn's disease. Gastroenterol Jpn 1991;26:514522.

50. Slezak P, Rubio C, Blomqvist L, Nakano H, Befrits R. Duodenal adenocarcinoma in Crohn's disease of the small bowel: a case report. Gastrointest Radiol 1991;16:15-17

51. Lashner BA. Risk factors for small bowel cancer in Crohn's disease. Dig Dis Sci 1992;37:1179-1184

52. Michelassi F, Testa G, Pomidor WJ, Lashner BA, Block GE. Adenocarcinoma complicating Crohn's disease. Dis Colon Rectum 1993;36:654-661.

53. Moesgaard F, Knudsen JT, Christensen N. Adenocarcinoma of the small intestine associated with Crohn's disease. Acta Chir Scand 1979;145:577580 .

54. Heathcote J, Knauer CM, Oakes D, Archibald RW. Perforation of an adenocarcinoma of the small bowel affected by regional enteritis. Gut 1980;21:1093-1096.

55. Gyde SN, Prior P, Macartney JC, Thompson H, Waterhouse JA, Allan RN Malignancy in Crohn's disease. Gut 1980;21:1024-1029.

56. Traube J, Simpson S, Riddell RH, Levin B, Kirsner JB. Crohn's disease and adenocarcinoma of the bowel. Dig Dis Sci 1980;25:939-944.

57. Castellano TJ, Frank MS, Brandt LJ, Mahadevia P. Metachronous carcinoma complicating Crohn's disease. Arch Intern Med 1981;141:1074-1075. 
58. Hawker PC, Gyde SN, Thompson H, Allan RN. Adenocarcinoma of the small intestine complicating Crohn's disease. Gut 1982;23:188-193.

59. Van Landingham SB, Kluppel S, Symmonds R Jr, Snyder SK. Coexisting carcinoid tumor and Crohn's disease. J Surg Oncol 1983;24:310-314.

60. Cooper DJ, Weinstein MA, Korelitz BI. Complications of Crohn's disease predisposing to dysplasia and cancer of the intestinal tract: considerations of a surveillance program. J Clin Gastroenterol 1984;6:217-224.

61. Bearzi I, Ranaldi R. Small bowel adenocarcinoma and Crohn's disease: report of a case with differing histogenetic patterns. Histopathology 1985:9:345-357.

62. Keane T, Lane B, O'Donoghue DP, Hyland J. Small bowel adenocarcinoma and Crohn's disease. Ir J Med Sci 1986;155:439-440.

63. Fell J, Snooks S. Small bowel adenocarcinoma complicating Crohn's disease. J R Soc Med 1987;80:51-52.

64. Petras RE, Mir-Madjlessi SH, Farmer RG. Crohn's disease and intestinal carcinoma. A report of 11 cases with emphasis on associated epithelial dysplasia. Gastroenterology 1987;93:1307-1314.

65. Senay E, Sachar DB, Keohane M, Greenstein AJ. Small bowel carcinoma in Crohn's disease. Distinguishing features and risk factors. Cancer 1989;63:360-363

66. Richards ME, Rickert RR, Nance FC. Crohn's disease-associated carcinoma. A poorly recognized complication of inflammatory bowel disease. Ann Surg 1989;209:764-773.

67. Savoca PE, Ballantyne GH, Cahow CE. Gastrointestinal malignancies in Crohn's disease. A 20-year experience. Dis Colon Rectum 1990;33:7-11.

68. Marchetti F, Fazio VW, Ozuner G. Adenocarcinoma arising from a strictureplasty site in Crohn's disease. Report of a case. Dis Colon Rectum 1996;39:1315-1321.

69. Wide JM, Loughran CF, Shoker BS. Crohn's disease, calculi and cancer: a report of two cases. Clin Radiol 1996;51:651-653.

70. Balaji V, Thompson MR, Marley NJ, Golding PL. Occult small bowel adenocarcinoma in a Crohn's stricture. J R Soc Med 1997:90:45.

71. Rashid A, Hamilton SR. Genetic alterations in sporadic and Crohn'sassociated adenocarcinomas of the small intestine. Gastroenterology 1997;113:127-135

72. Christodoulou D, Skopelitou AS, Katsanos KH, Katsios C, Agnantis N, Price A, Kappas A, Tsianos EV. Small bowel adenocarcinoma presenting as a first manifestation of Crohn's disease: report of a case, and a literature review. Eur J Gastroenterol Hepatol 2002;14:805-810.

73. Barwood N, Platell C. Case report: adenocarcinoma arising in a Crohn's stricture of the jejunum. J Gastroenterol Hepatol 1999;14:1132-1134.

74. Koga H, Aoyagi K, Hizawa K, Iida M, Jo Y, Yao T, Oohata Y, Mibu R, Fujishima M. Rapidly and infiltratively growing Crohn's carcinoma of the small bowel: serial radiologic findings and a review of the literature. Clin Imaging 1999;23:298-301

75. Jaskowiak NT, Michelassi F. Adenocarcinoma at a strictureplasty site in Crohn's disease: report of a case. Dis Colon Rectum 2001;44:284-287.

76. Gusakova I, Mermershtain W, Cohen Y, Ariad S. Small bowel adenocarcinoma in crohn disease patient complicated by microangiopathic hemolytic anemia. Am J Clin Oncol 2003;26:483-485

77. Jess $\mathrm{T}$, Winther KV, Munkholm P, Langholz E, Binder V. Intestinal and extra-intestinal cancer in Crohn's disease: follow-up of a populationbased cohort in Copenhagen County, Denmark. Aliment Pharmacol Ther 2004;19:287-293

78. Partridge SK, Hodin RA. Small bowel adenocarcinoma at a strictureplasty site in a patient with Crohn's disease: report of a case. Dis Colon Rectum 2004:47:778-781.

79. Tirkes AT, Duerinckx AJ. Adenocarcinoma of the ileum in Crohn disease Abdom Imaging 2005;30:671-673.
80. Palascak-Juif V, Bouvier AM, Cosnes J, Flourié B, Bouché O, Cadiot G, Lémann M, Bonaz B, Denet C, Marteau P, Gambiez L, Beaugerie L, Faivre J, Carbonnel F. Small bowel adenocarcinoma in patients with Crohn's disease compared with small bowel adenocarcinoma de novo. Inflamm Bowel Dis 2005; 11:828-832.

81. Kronberger IE, Graziadei IW, Vogel W. Small bowel adenocarcinoma in Crohn's disease: a case report and review of literature. World J Gastroenterol 2006;12:1317-1320.

82. Menon AM, Mirza AH, Moolla S, Morton DG. Adenocarcinoma of the small bowel arising from a previous strictureplasty for Crohn's disease: report of a case. Dis Colon Rectum 2007:50:257-259.

83. Dossett LA, White LM, Welch DC, Herline AJ, Muldoon RL, Schwartz DA, Wise PE. Small bowel adenocarcinoma complicating Crohn's disease: case series and review of the literature. Am Surg 2007;73:1181-1187.

84. Kodaira C, Osawa S, Mochizuki C, Sato Y, Nishino M, Yamada T, Takayanagi Y, Takagaki K, Sugimoto K, Kanaoka S, Furuta T, Ikuma M. A case of small bowel adenocarcinoma in a patient with Crohn's disease detected by PET/ CT and double-balloon enteroscopy. World J Gastroenterol 2009;15:17741778.

85. Soyer P, Hristova L, Boudghène F, Hoeffel C, Dray X, Laurent V, Fishman EK, Boudiaf M. Small bowel adenocarcinoma in Crohn disease: CTenterography features with pathological correlation. Abdom Imaging 2012:37:338-349

86. Place V, Hristova L, Dray X, Lavergne-Slove A, Boudiaf M, Soyer P. Ileal adenocarcinoma in Crohn's disease: magnetic resonance enterography features. Clin Imaging 2012;36:24-28.

87. Sogawa M, Watanabe K, Egashira Y, Maeda K, Morimoto K, Noguchi A, Kamata N, Yamagami H, Watanabe T, Tominaga K, Fujiwara Y, Oshitani N Arakawa T. Precise endoscopic and pathologic features in a Crohn's disease case with two fistula-associated small bowel adenocarcinomas complicated by an anal canal adenocarcinoma. Intern Med 2013;52:445-449.

88. Yano Y, Matsui T, Hirai F, Okado Y, Sato Y, Tsurumi K, Ishikawa S, Beppu T, Koga A, Yoshizawa N, Higashi D, Futami K. Cancer risk in Japanese Crohn's disease patients: investigation of the standardized incidence ratio. J Gastroenterol Hepatol 2013;28:1300-1305.

89. Svrcek M, Piton G, Cosnes J, Beaugerie L, Vermeire S, Geboes K, Lemoine A, Cervera P, El-Murr N, Dumont S, Scriva A, Lascols O, Ardizzone S, Fociani P, Savoye G, Le Pessot F, Novacek G, Wrba F, Colombel JF, Leteurtre E, Bouhnik Y, Cazals-Hatem D, Cadiot G, Diebold MD, Rahier JF, Delos M, Fléjou JF, Carbonnel F. Small bowel adenocarcinomas complicating Crohn's disease are associated with dysplasia: a pathological and molecular study. Inflamm Bowel Dis 2014;20:1584-1592.

90. Condino G, Aratari A, Papi C, Catarci M. Gastrointestinal bleeding and severe anaemia: An uncommon presentation of small bowel carcinoma complicating ileal Crohn's disease. Dig Liver Dis 2015;47:899-900.

91. Coelho R, Silva M, Gaspar R, Silva R, Paiva D, Lopes J, Lopes S, Manuel Lopes J, Magro F, Macedo G. "A book should not be judged by its cover": two cases of intestinal adenocarcinoma as the first manifestation of Crohn's disease. Int J Colorectal Dis 2016;31:1061-1062.

92. Duggan E, Steinhagen RM. Small bowel carcinoma in the setting of long standing crohnâ s disease. Colorectal Cancer. 2016. Available from: https:// colorectal-cancer.imedpub.com/small-bowel-carcinoma-in-the-settingoflong-standing-crohns-disease.php?aid $=14848$

93. Gillen CD, Wilson CA, Walmsley RS, Sanders DS, O'Dwyer ST, Allan RN. Occult small bowel adenocarcinoma complicating Crohn's disease: a report of three cases. Postgrad Med J 1995;71:172-174.

94. Kobe A, Posabella A, Tampakis A, von Fluee M, Bolli M. Crohn's diseaseassociated large and small bowel adenocarcinoma with peritoneal carcinomatosis: two case reports. Int J Colorectal Dis 2016;31:1491-1492.

95. Whitcomb E, Liu X, Xiao SY. Crohn enteritis-associated small bowel adenocarcinomas exhibit gastric differentiation. Hum Pathol 2014;45:359367. 
96. Elriz K, Carrat F, Carbonnel F, Marthey L, Bouvier AM, Beaugerie L. Incidence, presentation, and prognosis of small bowel adenocarcinoma in patients with small bowel Crohn's disease: a prospective observational study. Inflamm Bowel Dis 2013;19:1823-1826.

97. Drukker L, Edden Y, Reissman P. Adenocarcinoma of the small bowel in a patient with occlusive Crohn's disease. World J Gastrointest Oncol 2012;4:184-186.

98. Baars JE, Thijs JC, Bac DJ, Ter Borg PC, Kuipers EJ, van der Woude CJ. Small bowel carcinoma mimicking a relapse of Crohn's disease: a case series. J Crohns Colitis 2011;5:152-156.

99. Seirafi M, Cazals-Hatem D, Bouhnik Y. Adenocarcinoma revealing ileal Crohn's disease. Clin Gastroenterol Hepatol 2011;9:e21-22.

100. Mizushima T, Ohno Y, Nakajima K, Kai Y, Iijima H, Sekimoto M, Nishida T, Nezu R, Ito T, Doki Y, Mori M. Malignancy in Crohn's disease: incidence and clinical characteristics in Japan. Digestion 2010;81:265-270.

101. McGowan CE, Lagares-Garcia JA, Bhattacharya B. Retained capsule endoscope leading to the identification of small bowel adenocarcinoma in a patient with undiagnosed Crohn disease. Ann Diagn Pathol 2009;13:390-393

102. Mastoraki A, Konstantiadou I, Papanikolaou I, Christodolou S, Sakorafas G, Peros G. Adenocarcinoma of the small intestine complicating Crohn's disease. Int J Colorectal Dis 2009;24:1245-1246.

103. Aurello P, Dente M, D’Angelo F, Nigri G, Cescon M, Ramacciato G. Intestinal occlusion resulting from a small bowel adenocarcinoma as first onset of Crohn's disease in a healthy patient. Am Sur 2009;75:189-190.

104. Tougeron D, Lefebure B, Savoye G, Tuech JJ, di Fiore F, Michel P. Smallbowel adenocarcinoma in patient with Crohn's disease: report of a series of three cases. Scand J Gastroenterol 2008;43:1397-1400.

105. Reddy VB, Aslanian H, Suh N, Longo WE. Asymptomatic ileal adenocarcinoma in the setting of undiagnosed Crohn's disease. World J Gastroenterol 2008;14:4690-4693.

106. Watermeyer G, Locketz M, Govender D, Mall A. Crohn's disease-associated small bowel adenocarcinoma with pre-existing low-grade dysplasia: a case report. Am J Gastroenterol 2007;102:1545-1546.

107. Cioffi U, De Simone M, Ferrero S, Ciulla MM, Lemos A, Avesani EC. Synchronous adenocarcinoma and carcinoid tumor of the terminal ileum in a Crohn's disease patient. BMC Cancer 2005;5:157.

108. Shenderey RL, Thompson N, Mansfield JC, Rees C. Adenocarcinoma as a complication of small bowel Crohn's disease. Eur J Gastroenterol Hepatol 2005; 17:1255-1257

109. Yamamoto T, Bain IM, Allan RN, Keighley MR. An audit of strictureplasty for small-bowel Crohn's disease. Dis Colon Rectum 1999;42:797-803.

110. Uesugi H, Mitomi H, Sada M, Takahashi H, Kobayashi K, Igarashi M, Katsumata T, Ihara A, Ohtani Y, Ikeda S, Okayasu I. A case of adenocarcinoma of the small intestine in a Japanese patient with Crohn disease: a report with immunohistochemical and oncogenic analyses. Scand J Gastroenterol 1999;34:1162-1167.

111. Auber F, Gambiez L, Desreumaux P, Mudry J, Lecomte-Houcke M, Cortot A, Quandalle P, Colombel JF. Mixed adenocarcinoid tumor and Crohn's disease. J Clin Gastroenterol 1998;26:353-354.

112. Weedon DD, Shorter RG, Ilstrup DM, Huizenga KA, Taylor WF. Crohn's disease and cancer. N Engl J Med 1973;289:1099-1103.

113. Cuvelier C, Bekaert E, De Potter C, Pauwels C, De Vos M, Roels H. Crohn's disease with adenocarcinoma and dysplasia. Macroscopical, histological, and immunohistochemical aspects of two cases. Am J Surg Pathol 1989;13:187-196.

114. Boltin D, Levi Z, Halpern M, Fraser GM. Concurrent small bowel adenocarcinoma and carcinoid tumor in Crohn's disease-Case report and literature review. J Crohns Colitis 2011;5:461-464.
115. Chan RC, Katelaris PH, Stewart P, Lin BP. Small bowel adenocarcinoma with high levels of microsatellite instability in Crohn's disease. Hum Pathol 2006:37:631-634.

116. Jess T, Loftus EV Jr, Velayos FS, Harmsen WS, Zinsmeister AR, Smyrk TC, Schleck CD, Tremaine WJ, Melton 3rd LJ, Munkholm P, Sandborn WJ. Risk of intestinal cancer in inflammatory bowel disease: a populationbased study from olmsted county, Minnesota. Gastroenterology 2006;130:1039-1046.

117. Ben-Asher H. Adenocarcinoma of the ileum complicating regional enteritis. Am J Gastroenterol 1971;55:391-398.

118. Ellamushi HE, Smith IS. Small bowel adenocarcinoma complicating Crohn's disease. Scott Med J 1992;37:54-55.

119. Munkholm P, Langholz E, Davidsen M, Binder V. Intestinal cancer risk and mortality in patients with Crohn's disease. Gastroenterology 1993;105:1716-1723.

120. Kersting S, Bruewer M, Laukoetter MG, Rijcken EM, Mennigen R, Buerger $\mathrm{H}$, Senninger N, Krieglstein CF. Intestinal cancer in patients with Crohn's disease. Int J Colorectal Dis 2007;22:411-417.

121. Mohan IV, Kurian KM, Howd A. Crohn's disease presenting as adenocarcinoma of the small bowel. Eur J Gastroenterol Hepatol 1998; 10:431-432.

122. Jess T, Horvath-Puho E, Fallingborg J, Rasmussen HH, Jacobsen BA. Cancer risk in inflammatory bowel disease according to patient phenotype and treatment: a Danish population-based cohort study. Am J Gastroenterol 2013;108:1869-1876.

123. Institute NC. Cancer Stat Facts: Small Intestine Cancer. https://seer. cancer.gov/statfacts/html/smint.html (Accessed March 1, 2018)

124. Duerr D, Ellard S, Zhai Y, Taylor M, Rao S. A Retrospective review of chemotherapy for patients with small bowel adenocarcinoma in British Columbia. J Cancer 2016;7:2290-2295.

125. Raskov H, Burcharth J, Pommergaard HC. Linking gut microbiota to colorectal cancer. J Cancer 2017;8:3378-3395.

126. Bilimoria KY, Bentrem DJ, Wayne JD, Ko CY, Bennett CL, Talamonti MS. Small bowel cancer in the United States: changes in epidemiology, treatment, and survival over the last 20 years. Ann Surg 2009;249:63-71.

127. Delaunoit T, Neczyporenko F, Limburg PJ, Erlichman C. Pathogenesis and risk factors of small bowel adenocarcinoma: a colorectal cancer sibling? Am J Gastroenterol 2005;100:703-710.

128. Kern SE, Redston M, Seymour AB, Caldas C, Powell SM, Kornacki S, Kinzler KW. Molecular genetic profiles of colitis-associated neoplasms. Gastroenterology 1994;107:420-428.

129. Redston MS, Papadopoulos N, Caldas C, Kinzler KW, Kern SE. Common occurrence of APC and K-ras gene mutations in the spectrum of colitisassociated neoplasias. Gastroenterology 1995;108:383-392.

130. Maglinte DD, Kelvin FM, O'Connor K, Lappas JC, Chernish SM. Current status of small bowel radiography. Abdom Imaging 1996;21:247-257.

131. Weber NK, Fletcher JG, Fidler JL, Barlow JM, Pruthi S, Loftus Jr EV, Pardi DS, Smyrk TC, Becker BD, Pasha SF, Bruining DH. Clinical characteristics and imaging features of small bowel adenocarcinomas in Crohn's disease. Abdom Imaging 2015;40:1060-1067.

132. Bessette JR, Maglinte DD, Kelvin FM, Chernish SM. Primary malignant tumors in the small bowel: a comparison of the small-bowel enema and conventional follow-through examination. AJR Am J Roentgenol 1989;153:741-744

133. Wiarda BM, Mensink PB, Heine DGN, Stolk M, Dees J, Hazenberg H, Stoker J, van der Woude CJ, Kuipers EJ. Small bowel Crohn's disease: MR enteroclysis and capsule endoscopy compared to balloon-assisted enteroscopy. Abdom Imaging 2012;37:397-403. 
134. Lioe TF, Biggart JD. Primary adenocarcinoma of the jejunum and ileum: clinicopathological review of 25 cases. J Clin Pathol 1990;43:533-536.

135. Singhal N, Singhal D. Adjuvant chemotherapy for small intestine adenocarcinoma. Cochrane Database Syst Rev 2007:Cd005202.

136. Overman MJ, Varadhachary GR, Kopetz S, Adinin R, Lin E, Morris JS, Eng C, Abbruzzese JL, Wolff RA. Phase II study of capecitabine and oxaliplatin for advanced adenocarcinoma of the small bowel and ampulla of Vater. J Clin Oncol 2009;27:2598-2603.

137. Bakaeen FG, Murr MM, Sarr MG, Thompson GB, Farnell MB, Nagorney DM, Farley DR, van Heerden JA, Wiersema LM, Schleck CD, Donohue JH.
What prognostic factors are important in duodenal adenocarcinoma? Arch Surg 2000;135:635-641.

138. Abrahams NA, Halverson A, Fazio VW, Rybicki LA, Goldblum JR. Adenocarcinoma of the small bowel: a study of 37 cases with emphasis on histologic prognostic factors. Dis Colon Rectum 2002;45:1496-1502.

139. Bruckner HW, Hrehorovich VR, Sawhney HS, Meeus SI, Coopeman AM. Chemotherapeutic management of small bowel adenocarcinoma associated with Crohn's disease. J Chemother 2006;18:545-548. 